\title{
Mature Placental Teratoma: A Case Report
}

\author{
Najmeh Nasiri Khormoji ${ }^{1}$, Vahid Soleimani ${ }^{2}$, Shahrzad Sheikhhasani ${ }^{1}$,*
}

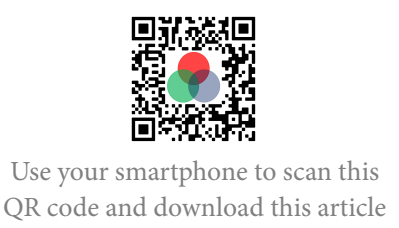

${ }^{1}$ Department of Obstetrics and Gynecology, Labour ward, Imam Khomeini Hospital Complex, Tehran University of Medical Sciences, Tehran, Iran

${ }^{2}$ Department of Pathology, Cancer institute, Imam Khomeini Hospital Complex, Tehran University of Medical Sciences, Tehran, Iran

\section{Correspondence}

Shahrzad Sheikhhasani, Department of Obstetrics and Gynecology, Labour ward, Imam Khomeini Hospital Complex, Tehran University of Medical Sciences, Tehran, Iran

Email:

shahrzad.sheikhhasani@yahoo.com

History

- Received: Nov 11, 2021

- Accepted: Dec 26, 2021

- Published: Jan 22, 2022

DOI : 10.15419/bmrat.v9i1.718

\section{Check for updates}

\section{Copyright}

(C) Biomedpress. This is an openaccess article distributed under the terms of the Creative Commons Attribution 4.0 International license.

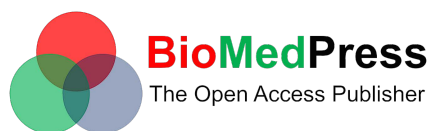

\begin{abstract}
Introduction: Placental teratoma is an uncommon, non-trophoblastic benign tumor. Since the first description of this type of tumor by Morvilli in 1925, only a few cases of this abnormality have been diagnosed and reported. Case presentation: We describe here a 35-year-old pregnant woman admitted for an elective cesarean section. The placenta and membranes were delivered spontaneously. After delivering the placenta, a tumor mass containing hair was detected between the extraplacental amnion and chorion. On gross examination, a singleton placenta weighing 173 g, measuring $15 \times 11 \mathrm{~cm}$ in area and $5.5 \mathrm{~cm}$ thick, with an attached cord and membranes, was observed. Microscopic examination showed orthokeratinized stratified squamous epithelium with underlying hair follicles, telangiectatic vessels, and sebaceous glands accompanied by subcutaneous fat. The fat also contained fibrocollagenous bundles. In addition, interconnecting bone trabecula rimmed by osteoblasts and attached mature cartilage were also found. Conclusion: An awareness of placental teratoma from a pathological perspective is needed to include this anomaly in the differential diagnosis of benign placental nodules, obtain more information about this unusual lesion, and to conduct more studies on this prenatal abnormality.

Key words: germ cell tumors, placenta, teratoma
\end{abstract}

\section{INTRODUCTION}

Teratomas are a type of germ cell tumor and can be divided into two types: mature and immature. These tumors contain multiple germ cell layers and are made up of several different types of tissue, such as hair, fat, and bone. The most common sites for these tumors are the ovary, testis, anterior mediastinum, posterior peritoneum, and pre-sacral region. Ovarian teratoma accounts for 15 to $20 \%$ of all ovarian tumors. Placental teratoma is considered to be a rare, nontrophoblastic benign tumor ${ }^{1,2}$. Since the first description by Morvilli in 1925, only a few cases of placental teratoma have been diagnosed and reported ${ }^{3}$. In all cases identified, the teratoma was located between the amnion and chorion, usually on the fetal surface of the placenta. Placental teratomas are very similar to fetus amorphous, but the umbilical cord and skeletal central structure are not detected in the teratoma $^{4,5}$. In one case report, the teratoma was mistaken for an encephalocele ${ }^{6}$. Prenatal diagnosis of placental teratoma is important because most are benign and do not appear to increase the risk of congenital malformations or complications of a normal pregnancy ${ }^{1}$. However, a placental teratoma may present a diagnostic challenge. In this report, we describe a placental teratoma that did not lead to obstetrical complications. Only a few such cases have been reported globally, and none of them in Iran.

\section{CASE PRESENTATION}

A 35-year-old pregnant woman with G4L2D2 (twin) REPIV, was admitted at 37 weeks +1 day for an elective cesarean section (post previa with focal accreta). Up to the $15^{\text {th }}$ week of pregnancy, regular follow-up was carried out for gestational diabetes, which was controlled with diet. The patient's previous delivery was by cesarean section. The patient's blood group was $\mathrm{B}+$, and she had a normal delivery of a female infant weighing $2500 \mathrm{~g}$, with an Apgar score of 9/10. The placenta and membranes were delivered spontaneously. The placenta was previa but showed no focal accreta. After delivering the placenta, a tumor mass, containing hair, was found between the extraplacental amnion and the chorion (Figure 1). Although the patient had received antenatal care, the tumor was not identified antenatally by ultrasound. Sex chromatin and ploidy examination were not performed in this patient.

Upon gross examination, a singleton placenta weighing $173 \mathrm{~g}$ and measuring $15 \times 11 \mathrm{~cm}$ in area and $5.5 \mathrm{~cm}$ in thickness, with an attached cord and membranes, was observed. The umbilical cord was inserted in an unusual manner and measured $15 \mathrm{~cm}$ in length and $1 \mathrm{~cm}$ in diameter. A cross-section of the cord revealed two vessels. The membranes were unremarkable and measured $23 \times 16 \mathrm{~cm}$ in area and 1 $\mathrm{cm}$ in thickness. An excised section of the placenta 

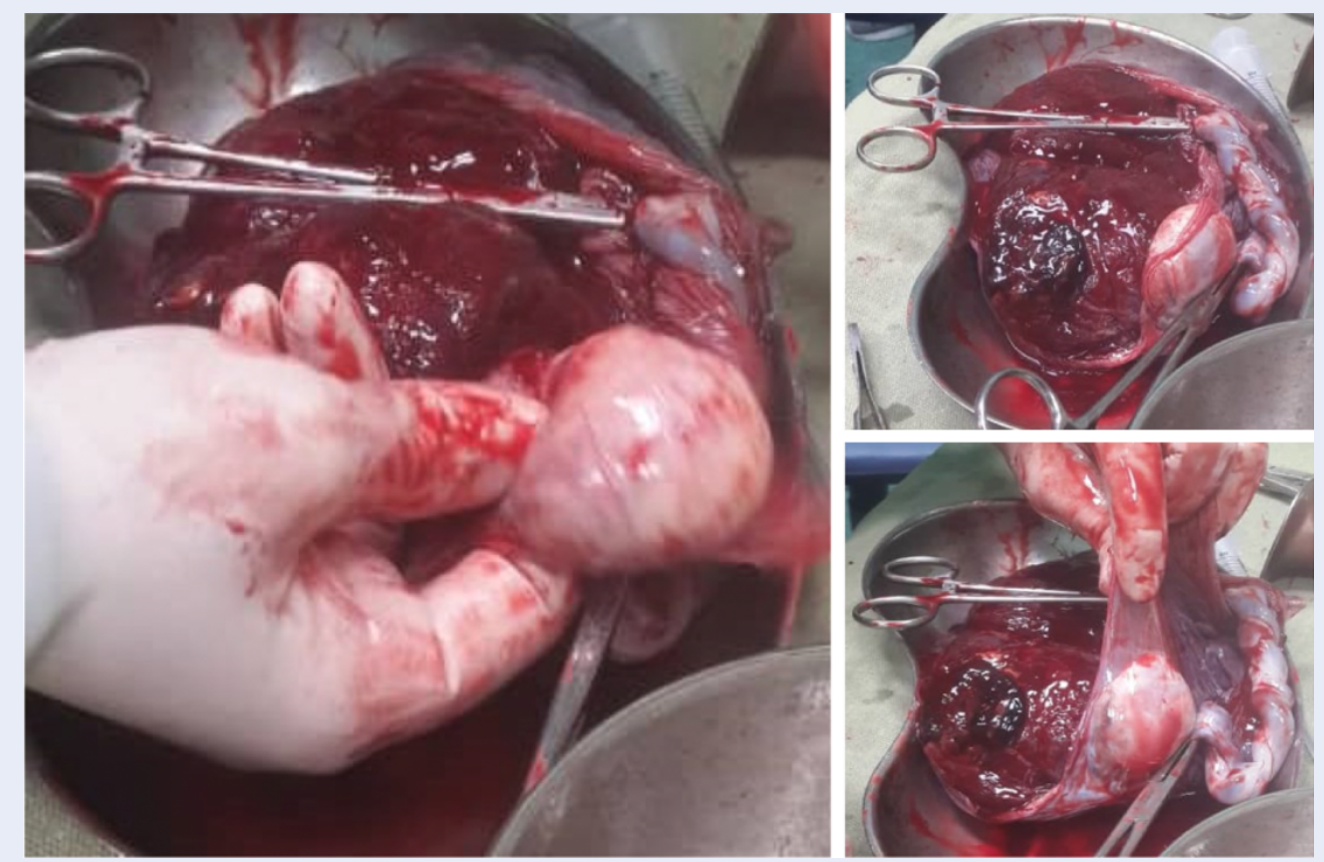

Figure 1: Macroscopic feature of placental teratoma. Placental mass with rubbery consistency measuring $4 \times$ $3.5 \times 1.5 \mathrm{~cm}$, situated between amniotic and chorionic membranes supplied by placental vessels separately from umbilical cord vessels. https://doi.org/10.6084/m9.figshare.18865283.v1
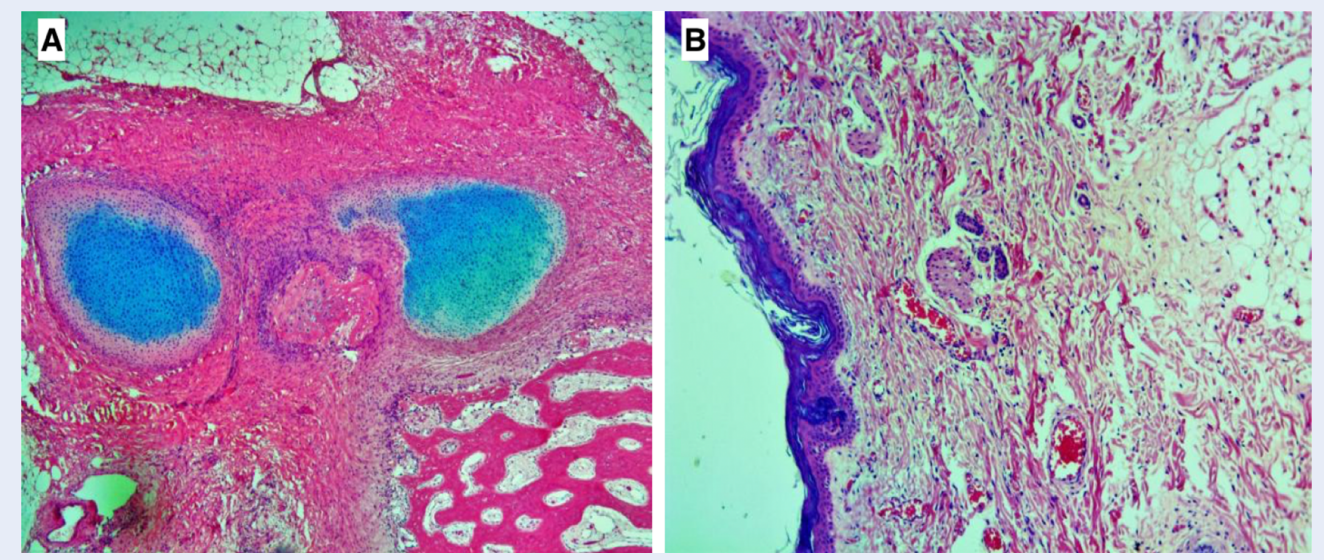

Figure 2: Microscopic pictures. A) Subcutaneous mature fat within fibrocollagenous bundles as well as interconnecting bone trabecularrimmed by osteoblasts and attached mature cartilage, B) Keratinizing squamous epithelium with hair follicles, telangiectasia vessels and sebaceous glands accompanied by subcutaneous fat (H\&E sections $\times 100$ ). https://doi.org/10.6084/m9.figshare.18865292.v1 
showed no obvious lesions. A mass with a rubbery consistency measured $4 \times 3.5 \times 1.5 \mathrm{~cm}$. A vessel through this mass was connected to the placenta at a peripheral aspect and a distance of $4 \mathrm{~cm}$ from the umbilical cord and was supplied by a vascular structure originating from the placenta.

Microscopic examination showed orthokeratinized stratified squamous epithelium with underlying hair follicles, telangiectatic vessels, and sebaceous glands accompanied by subcutaneous fat, which was transversed by fibrocollagenous bundles, as well as interconnecting bone trabecula rimmed by osteoblasts and attached mature cartilage (Figure 2).

\section{DISCUSSION}

Tumors of the placenta are divided into trophoblastic and non-trophoblastic types, with the latter characterized as either primary or secondary. The most common type of non-trophoblastic and primary placental tumor is chorangioma, which occurs in $1 \%$ of all pregnancies ${ }^{7,8}$. The second most common nontrophoblastic and primary placental tumor is a teratoma, first described in 1925 by P. Morvilli ${ }^{3}$. Placental teratomas are rare tumors with an unclear histogenesis ${ }^{\mathbf{5 , 9}}$. Nicholson proposed the "included twin" hypothesis, in which it was suggested that the teratoma initiated from a twin fetus that was "included" or merged with its co-twin through an embryological anomaly ${ }^{10}$. Tavares and Oporto speculated that the teratoma cell line arises from two fused germ cells ${ }^{11}$. Fox et al. has proposed the "germ cell theory" as a potential mechanism. He believed that, in the primary phases of embryogenesis, the primitive gut evaginates into the umbilical cord, and germ cells from the gut migrate out and are deposited in the connective tissue of the umbilical cord, leading to the formation of a teratoma of the cord. If the germ cells continue to migrate until they reach the extraplacental membranes, they develop into an extraplacental membrane teratoma between the amnion and chorion ${ }^{12}$. The germ cell theory is currently more accepted than the "included twin" hypothesis ${ }^{6}$. Placental teratomas are typically $2-11 \mathrm{~cm}$ in length ${ }^{4}$. Microscopy shows mature tissues derived from the three germinative layers, but are lacking well-defined organization ${ }^{13,14}$. However, a case was recently reported in which an immature placental teratoma with evidence of necrosis and neuroepithelial elements was mixed with mature and immature tissue of ectodermal and mesodermal origin ${ }^{15}$. Prenatal diagnosis is possible by ultrasound, and such findings have been described as abnormalities on or adjacent to the placenta. Prenatal diagnosis can be based on various echogenic tissues such as calcifications, fat, and fluid. Calcification differentiates teratoma from other common tumors such as trophoblastic and chorioangioma ${ }^{14}$. Fetus amorphous is the primary differential diagnosis of placental teratoma and is diagnosed by ultrasound. Typically, no evidence of a skeletal axis is provided in pathology reports ${ }^{6,14}$. In 1991, Akimov described a single isolated case of a large placental teratoma that resulted in fetal asphyxia, possibly due to mechanical compression of the umbilical cord ${ }^{\mathbf{1 6}}$. Consequently, in masses greater than $10 \mathrm{~cm}$, regular prenatal and intrapartum monitoring of fetal wellbeing is recommended due to the potential for fetal hypoxia ${ }^{17}$. Placental teratoma is a benign tumor that typically has no adverse effect on the mother or fetus, but the potential for malignancy is unknown. Because of its benign features, prenatal diagnosis of other tumors is important. More information is needed on this rare abnormality.

\section{CONCLUSION}

An awareness of placental teratoma is important from a pathological perspective in order to include it as a possibility in the differential diagnosis of benign placental nodules, as well as obtain more information about this unusual aberration, and conduct more studies on this type of prenatal anomaly.

\section{ABBREVIATIONS}

None.

\section{ACKNOWLEDGMENTS}

None.

\section{AUTHOR'S CONTRIBUTIONS}

All authors equally contributed to the all parts of conceptualization and data collection. All authors read and approved the final draft of the manuscript.

\section{FUNDING}

None.

\section{AVAILABILITY OF DATA AND MATERIALS}

Data and materials used in the current study are available from the corresponding author on reasonable request.

\section{ETHICS APPROVAL AND CONSENT TO PARTICIPATE}

This study was conducted in accordance with the amended Declaration of Helsinki. The written informed consent was obtained from the patient. 


\section{CONSENT FOR PUBLICATION}

Not applicable.

\section{COMPETING INTERESTS}

The authors declare that they have no competing interests.

\section{REFERENCES}

1. Ahmed N, Kale V, Thakkar H, Hanchate V, Dhargalkar P. Sonographic diagnosis of placental teratoma. Journal of Clinical Ultrasound. 2004;32(2):98-101. PMID: 14750143. Available from: $10.1002 /$ jcu.10231.

2. Meinhard K, Dimitrov S, Nicolov A, Dimitrova V, Vassilev N. Placental teratoma: a case report. Pathology, Research and Practice. 1999;195(9):649-51. PMID: 10507085. Available from: 10.1016/S0344-0338(99)80130-7.

3. Morville P. Une teratoma placentaire. Gynecol Obstet (Paris). 1925;2:29-32.

4. Chandy RG, Korula A, Seshadri L. Teratoma of the placenta. Australian and New Zealand Journal of Obstetrics and Gynaecology. 2002;42(5):556-7. PMID: 12495112. Available from: 10.1111/j.0004-8666.2002.548_6.x.

5. Elagöz S, Aker H, Cetin A. Placental teratoma. A case report. European Journal of Obstetrics, Gynecology, and Reproductive Biology. 1998;80(2):263-5. PMID: 9846681. Available from: 10.1016/S0301-2115(98)00090-6.

6. Prashanth A, Lavanya R, Girisha KM, Mundkur A. Placental Teratoma presenting as a lobulated mass behind the neck of fetus: a case report. Case Reports in Obstetrics and Gynecology. 2012;2012:857230. PMID: 22779019. Available from: $10.1155 / 2012 / 857230$.
7. Sarmiento A, Quijano FE, Puccini G, Rodríguez N, Gómez PA. Corangioma placentario. Reporte de caso y revisión de la literatura. Revista Colombiana de Obstetricia y Ginecologia. 2008;59(1):62-7. Available from: 10.18597/rcog.433.

8. Gruca K, Ropacka M, Breborowicz GH. Non-trophoblastic placental tumors. Archives of Perinatal Medicine. 2011;17:113-7.

9. Shimojo $H$, Itoh $N$, Shigematsu $H$, Yamazaki T. Mature teratoma of the placenta. Pathology International. 1996;46(5):372-5. PMID: 8809884. Available from: 10.1111/ j.1440-1827.1996.tb03623.x.

10. Geoffrey H. Studies on tumour formation. By G. W. de P. Nicholson, M.A., M.B. , B.Ch., Late Professor of Pathology, Guy's Hospital, London. 1950. London: Butterworth \& Co. (Publishers) Ltd. .

11. Tavares AS. On the sex of cancer and teratomata cells. Lancet. 1955;268(6871):948-9. PMID: 14368916. Available from: 10. 1016/S0140-6736(55)90969-7.

12. Fox $\mathrm{H}$, Butler-Manuel R. A teratoma of the placenta. The Journal of Pathology and Bacteriology. 1964;88(1):137-40. PMID: 14194970. Available from: 10.1002/path.1700880118.

13. Gaffar BA, Hotait HY, Gamlouch SF, Swalaha NJ. Placental teratoma or fetus acardius amorphous? Hematology/Oncology and Stem Cell Therapy. 2008;1(1):57-61. PMID: 20063530 Available from: 10.1016/S1658-3876(08)50062-8.

14. Kudva R, Monappa V, Rai L. Placental teratoma: a diagnostic dilemma with fetus acardius amorphous. Indian Journal of Pathology \& Microbiology. 2010;53(2):378-9. PMID: 20551569. Available from: 10.4103/0377-4929.64293.

15. Shahzadi S. Immature placental teratoma. Journal of Postgraduate Medical Institute. 2014;28:324-7.

16. Akimov OV. [Giant teratoma of the placenta (acardius amorphus)]. Arkhiv Patologii. 1991;53(4):59-60. PMID: 1872694.

17. Tan G, Shiran M, Aireen I, Swaminathan M, Hayati A, Zaleha A. Large teratoma of the Placenta. The Internet Journal of Gynecology and Obstetrics. 2008;11:12. 
Ready to submit your manuscript? Choose Biomedpress and benefit from:

- Fast, convenient online submission

- Through peer-review by experienced researchers

- Rapid publication on acceptance

- Free of charge (without publication fees)

Learn more http://www.biomedpress.org/journals/
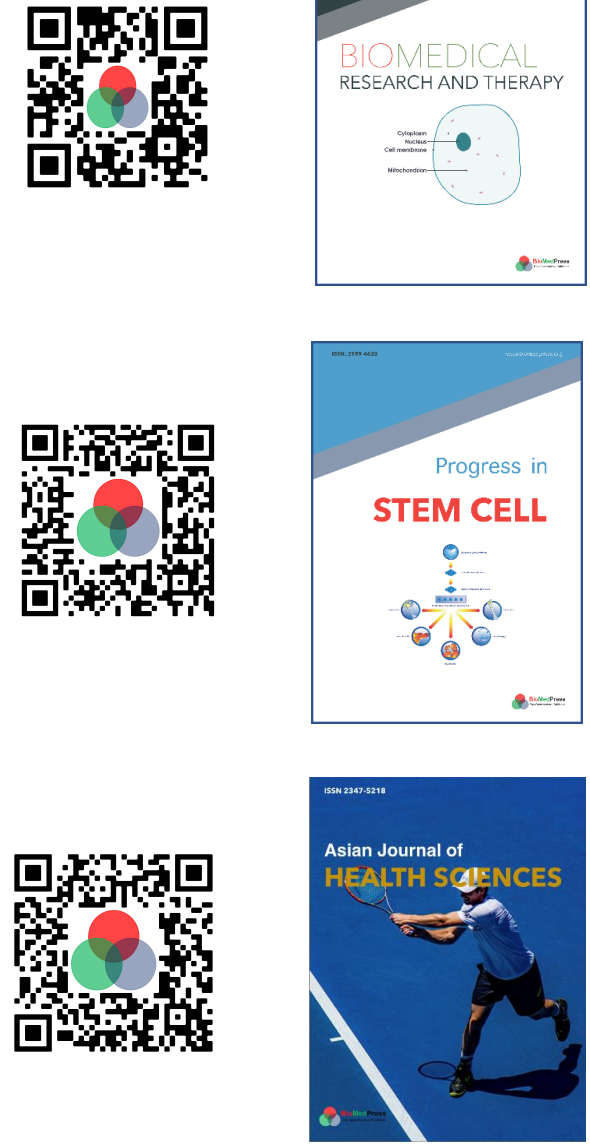

Asian Journal of Health Sciences

ISSN: 2347-5218

Indexed: Google Scholar

Acceptance Rate (2020): 72.89\%

Article Publishing Charge: Free

Submission to first editorial decision: 16.5 days

Biotechnological Research

ISSN: 2395-6763

Indexed: Google Scholar

Acceptance Rate (2020): $67.02 \%$

Article Publishing Charge: Free

Submission to first editorial decision: 28.5 days 